\title{
HYDROCHEMICAL EVALUATION AT LAMBARI RIVER, SÃO JOSÉ DOS CAMPOS (SP), BRAZIL
}

\author{
ISABELLA G. LEE \& DANIEL M. BONOTTO \\ Departamento de Geologia, Instituto de Geociências e Ciências Exatas - UNESP, Rio Claro, Brazil
}

\begin{abstract}
This paper describes a hydrochemical study held at Lambari river, a tributary of Paraíba do Sul river that is located at São José dos Campos city, São Paulo State, Brazil. Such drainage crosses the installations of the Henrique Lage Oil Refinery (REVAP), allowing identify possible pollutants inputs on the water resources due to the development of the industrial activities taking place there. Two sampling campaigns were realized in the wet seasons of 2019 and 2020 aiming to collect rainwater and surface water samples in 32 monitoring points. Physicochemical parameters (temperature, $\mathrm{pH}$, redox potential (Eh), electrical conductivity (EC), turbidity and dissolved oxygen), as well hydrochemical parameters $\left(\mathrm{Na}^{+}, \mathrm{K}^{+}, \mathrm{Ca}^{2+}, \mathrm{Mg}^{2+}\right.$, alkalinity, $\mathrm{Cl}^{-}, \mathrm{NO}_{3}^{-}, \mathrm{SO}_{4}^{2-}$, surfactants, tannin-lignin, benzene, toluene, ethylbenzene and xylene (BTEX) and other organic compounds) and dissolved radon $\left({ }^{222} \mathrm{Rn}\right)$ provided a robust dataset for understanding the major processes related to modifications in the water quality. Direct relationship was found between EC and total dissolved solids (TDS) in the waters of Lambari river as often described elsewhere. Sodium and chloride were the two dominant ions that justified the EC-TDS relationship. Additionally, both EC and TDS as well correlated significantly with alkalinity (bicarbonate). The rainwater is impoverished in the dissolved constituents relatively to the surface waters, which acquire them during the rainfall interactions with the soil covers/rock surfaces or anthropogenic inputs into the Lambari river channel. The Piper diagram highlighted that the hydrochemical facies of rainwater and surface waters are the same, i.e. sodium bicarbonate. The Gibbs boomerang diagrams suggested dominant influence of the dilution effects by rainwater in the hydrochemical composition of the surface waters of Lambari river. Dissolved oxygen and radon correlated significantly, while the analytical data did not indicate changes in the concentration of BTEX and other organic compounds in the waters of Lambari river due to the industrial activities developed by REVAP.

Keywords: Brazil, hydrochemical parameters, Lambari river, oil refinery, Paraiba do Sul basin, rainwater, São José dos Campos city, surface waters
\end{abstract}

\section{INTRODUCTION}

One of the main sources of water supply for society is surface water, which is constantly impacted by human activities, usually related to industrial practices. Thus, hydrochemical studies focusing on surface water quality are necessary for the proper planning and management of water resources in a region

This paper reports a hydrochemical investigation associated with the previous studies carried out by [1]. The work focuses on a portion of the Paraíba do Sul river basin, in the Paraíba valley region, an important economic axis between São Paulo and Rio de Janeiro in Brazil, which has a great demand for water resources due to the occurrence of cities of great and medium size such as Jacareí, Taubaté, Aparecida do Norte and São José dos Campos at São Paulo State.

The research was conducted on the Lambari river (or Alambari river) (Fig. 1), a tributary of the Paraíba do Sul river, which flows through the installations of Henrique Lage Oil Refinery (REVAP), one of the most remarkable Petrobras oil refineries, located in the city of São José dos Campos, east of São Paulo State (Fig. 1). It is worth mentioning that São José dos Campos city hosts the largest aerospace complex in Latin America, in addition to being an important research, technology and warlike materials pole in the country. 
The REVAP's activities can release several aliphatic and aromatic hydrocarbons, such as benzene, toluene, ethylbenzene and xylene (BTEX) into the waters of Lambari river. Such compounds are fat-soluble and toxic to humans, acting as central nervous system depressants and presenting toxicity even in low concentrations $[2,3]$. In order to evaluate this possibility, an integrated hydrochemical study was held in that area, focusing physicochemical and chemical parameters such as major inorganic constituents, BTEX and other organic compounds, surfactants and tannin-lignin. The target area corresponded to Lambari river monitored in several points located upstream and downstream of the oil refinery.

To better understand the surface water-groundwater interactions, radon ${ }^{222} \mathrm{Rn}$, half-life 3.82 days) was also analysed. It is a noble gas belonging to the ${ }^{238} \mathrm{U}(4 \mathrm{n}+2)$ decay series [4] that escapes from the rocks and minerals to the surrounding fluid phase, such as groundwater and air, due to several factors like the total surface area of solids and ${ }^{238} \mathrm{U}\left({ }^{226} \mathrm{Ra}\right)$ concentration in them [5]. Radon also represents a hazard to human health as 3 to $14 \%$ of lung cancer cases in non-smokers in the U.S. is caused by ${ }^{222} \mathrm{Rn}$ exposure [6]. In surface waters, radon may be introduced into the liquid phase when the waters interact with soils possessing ${ }^{226} \mathrm{Ra}$ of natural occurrence or anthropogenic, mostly from the use of fertilizers [7].

\section{STUDY AREA}

The study area is located in the Paraíba do Sul river basin, which has an area of approximately 57,000 km² and covers three Brazilian states: São Paulo, Minas Gerais and Rio de Janeiro. The main watercourse in this basin is the Paraíba do Sul river, which is formed by the confluence of the Paraitinga and Paraibuna rivers, flowing into Atlantic Ocean at São João da Barra (Rio de Janeiro State) [8].

Paraíba do Sul river cuts São José dos Campos city at São Paulo State (Fig. 1), and its tributary Lambari river, focused in this study, is located in the High Paraíba do Sul sub-basin.

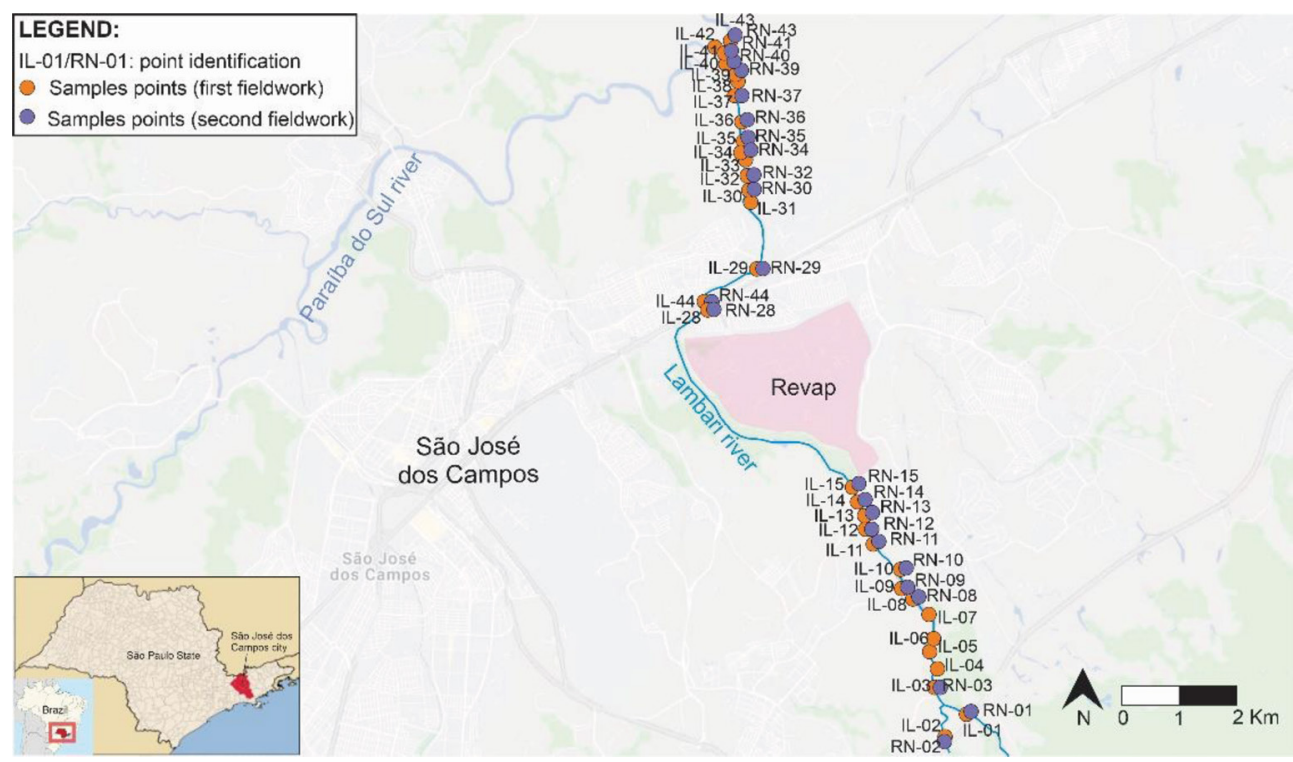

Figure 1: Location of the study area and of the monitoring points at Lambari river. 
Lambari river flows from southeast to northwest of São José dos Campos city and crosses the REVAP (Fig. 1). The major access to the study area is by Presidente Dutra highway (BR-116).

The study area is geologically inserted in the Taubate sedimentary basin, which presents a rift-type basin, with primary continental and syntectonic sedimentation, associated with fluvial and lacustrine environments. The sediments deposition occurred in two phases. The first corresponds to a syntectonic phase to the rift, responsible by deposition of sediments from Taubaté Group. The second is associated to a post-rift phase, responsible by deposition of sediments from Pindamonhangaba Formation and alluvial/colluvial deposits [9-11]. The Taubaté Group comprises the Formations Resende, Tremembé and São Paulo [12].

Geomorphologically, the study area is situated at Paraíba do Sul river valley that is a lowered surface embedded in Precambrian rocks limited by Mantiqueira mountain range at northwestern and Mar mountain range at southeastern [13].

In general, according to the Köppen and Geiger classification, the area's climate is warm and temperate. There is significant rainfall throughout the year, permeating between Cfa (subtropical ocean) and Aw (seasonal tropical with dry season in winter) [14]. The average annual temperature is $19.4^{\circ} \mathrm{C}$, and the average annual rainfall is about $1269 \mathrm{~mm}$ [15]. The remaining vegetation in the area is the Atlantic Forest that is dominant on the slopes of Mantiqueira Mountain Range and on the banks of Paraíba do Sul river.

\section{MATERIALS AND METHODS}

Two sampling campaigns were realized in the study area. The first was held in late October and early November 2019 as described by [1], and the second was carried out on December 4, 2020. The last involved the development of complementary analysis to those reported by [1], including the sampling of Lambari river waters and rainwater. Figure 1 shows the monitored points in both sampling campaigns held at Lambari river. Additionally, a rainwater sample (2 litres) was collected at São José dos Campos city on October 9, 2020, for chemical analysis.

Details for measurements of the physicochemical parameters (temperature, $\mathrm{pH}$, redox potential (Eh), electrical conductivity (EC) and turbidity), major constituents (sodium, potassium, calcium, magnesium, alkalinity, chloride, nitrate and sulphate), surfactants and tanninlignin are given in [1]. Most of these analyses were done by spectrophotometry, like silica (Hach method 8185 - Silicomolybdate Method) [16]. The summation of the concentration of the major dissolved cations $\left(\mathrm{Na}^{+}, \mathrm{K}^{+}, \mathrm{Ca}^{2+}, \mathrm{Mg}^{2+}\right)$, anions $\left(\mathrm{Cl}^{-}, \mathrm{SO}_{4}^{2-}, \mathrm{NO}_{3}^{-}, \mathrm{HCO}_{3}^{-}\right)$and silica in the analysed waters allowed determine the total dissolved solids (TDS).

The dissolved oxygen concentration in the water samples of Lambari river was measured in situ using a portable digital device Hanna - model HI 9146. The readings were performed immediately after the water collection. For Rn analyses, the water samples of Lambari river were collected in 250-mL glass flasks, avoiding as much as possible the exposure to atmospheric air. The flasks were duly identified and numbered and were previously washed and rinsed at the collection time with the water sampled, in order to avoid contamination. The samples were carefully handled and taken to LABIDRO-Isotopes and Hydrochemistry Laboratory, IGCE-UNESP - Rio Claro Campus, where the analysis proceeded.

Two additional samples (1 and 2) were collected upstream and downstream from REVAP for the analysis of BTEX and other organic compounds. Each sample was collected in two $40 \mathrm{~mL}$ flasks with teflon/silicone septum, containing a preservative for BTEX assays (eight drops of $\mathrm{HCl} 50 \%$ ). The samples were collected without any bubbles and kept refrigerated in a thermal box with ice at a temperature between $0^{\circ} \mathrm{C}$ and $10^{\circ} \mathrm{C}$ until they were taken to the Eurofins ASL Laboratory, Rio Claro city (São Paulo - Brazil), responsible for carrying out 
the analysis. The samples were analysed using gas chromatography (USEPA 8015C) with a flame ionization detector (model GC-FIDHS) and gas chromatography (USEPA 8260D) with a mass spectrometry (model GCMS-HS).

The radon dissolved in the water samples of Lambari river was analysed using RAD7 alpha particles detector coupled to accessory $\mathrm{RADH}_{2} \mathrm{O}$ from Durridge Co. The RAD7 utilizes a solid state alpha detector, comprising a Si semiconductor material that converts the energy of the alpha particles into an electrical signal [17]. The $\mathrm{RADH}_{2} \mathrm{O}$ accessory unit employed an aeration system in a closed circuit connecting the sample, RAD7 and a desiccant tube containing Drierite to humidity absorption [18]. Then, the air circulated through the sample during about 10 minutes, extracting radon until reaching an equilibrium state. The instrument display recorded the ${ }^{222} \mathrm{Rn}$ activity concentration data in water in $\mathrm{Bq} / \mathrm{m}^{3}$ that was converted to the SI unit $\mathrm{Bq} / \mathrm{L}$. The total counting time was 15 minutes for each sample, comprising three 5-minute cycles, and the final result corresponded to the mean value of the three readings. The detection limit corresponded to $0.004 \mathrm{~Bq} / \mathrm{L}$ [17]. The activity concentration was corrected from the time elapsed since the sampling until the readings.

The following analyses were done for the rainwater samples, adopting the same analytical protocols described by [1]: $\mathrm{pH}, \mathrm{EC}$, sodium, potassium, calcium, magnesium, alkalinity, chloride, nitrate, sulphate and silica.

Different hydrogeochemical diagrams (Piper, Schoeller, Gibbs) were used for the data analysis and interpretation, with the aid of QualiGraf 1.1 software (made available by FUNCEME-Ceará Meteorology and Water Foundation).

\section{RESULTS AND DISCUSSION}

\subsection{Major hydrochemical features}

Tables 1 and 2 show all results obtained in this study. The temperature of the surface waters measured in situ ranged from $24.6^{\circ} \mathrm{C}$ to $32.8^{\circ} \mathrm{C}$ (mean $=26.4^{\circ} \mathrm{C}$ ). The $\mathrm{pH}$ values indicated that the surface waters are almost neutral $($ mean $=6.8)$. The Eh values are between +260 and $+324 \mathrm{mV}$, except for the outlier value of the sample IL-02 $(-170 \mathrm{mV})$. Based on the $\mathrm{pH}$ and Eh data, the waters of the Lambari river can be classified as slightly oxidizing, except the sample IL-02 that is reduced as shown in the Eh-pH diagram (Fig. 2) for characterizing the type of environment where the water is flowing. The results of tannin-lignin and surfactants confirm that IL-02 has the highest value of these parameters and shows more influence of domestic effluents and decomposition of organic matter.

The EC of the surface water samples ranged from 72.6 to $214 \mu \mathrm{S} / \mathrm{cm}$, the alkalinity between 22 and $64 \mathrm{mg} / \mathrm{L}$ of $\mathrm{CaCO} 3$, the turbidity between 1 and $42 \mathrm{FTU}$, and the TDS from 47.77 to $120.97 \mathrm{mg} / \mathrm{L}$, except the sample IL-02, which showed values of $560 \mu \mathrm{S} / \mathrm{cm}$ (EC), $108 \mathrm{mg} / \mathrm{L}$ (alkalinity), 120 FTU (turbidity) and $299.85 \mathrm{mg} / \mathrm{L}$ (TDS) (Tables 1 and 2).

The hydrochemical monitoring of the surface waters indicated direct relationship of EC with TDS (Fig. 3) as also described by [19], among other. It is often recognized that sodium and chloride are the two dominant ions justifying the EC-TDS relationship as also confirmed the plots shown in Fig. 3 for the Na-EC and Cl-EC relationships in the same sampling points. Additionally, both EC and TDS as well correlated significantly with alkalinity (bicarbonate) as pointed out by [1]. Bicarbonate often takes a major role in the chemical composition of the surface waters [20]. 
Table 1: Physicochemical parameters, tannin-lignin (TL), surfactants and ${ }^{222} \mathrm{Rn}$ activity concentration obtained in the water samples analysed in this study.

\begin{tabular}{|c|c|c|c|c|c|c|c|c|c|}
\hline Sample & Temp. & Turbidity & $\mathrm{pH}$ & Eh & $\mathrm{EC}$ & ${ }^{1} \mathrm{O}_{2}$ & $\mathrm{TL}$ & Surfactants & ${ }^{1} \mathrm{Rn}-222$ \\
\hline code & $\left({ }^{\circ} \mathrm{C}\right)$ & (FTU) & & $(\mathrm{mV})$ & $(\mu \mathrm{S} / \mathrm{cm})$ & $(\mathrm{mg} / \mathrm{L})$ & $(\mathrm{mg} / \mathrm{L})$ & $(\mathrm{mg} / \mathrm{L})$ & $(\mathrm{Bq} / \mathrm{L})$ \\
\hline IL-01 & 32.8 & 22 & 7.26 & 260 & 112.8 & 7.87 & 0.2 & 0.025 & 5.93 \\
\hline IL-02 & 29.3 & 120 & 6.88 & -170 & 560.0 & 6.70 & 2.6 & 0.302 & 1.11 \\
\hline IL-03 & 25.7 & 2 & 7.07 & 266 & 145.0 & 9.02 & 0.2 & 0.016 & 1.02 \\
\hline IL-04 & 24.6 & 4 & 6.79 & 275 & 160.0 & $\mathrm{~nm}$ & 0.2 & 0.031 & $\mathrm{~nm}$ \\
\hline IL-05 & 24.6 & 4 & 6.98 & 288 & 138.9 & $\mathrm{~nm}$ & 0.2 & 0.018 & $\mathrm{~nm}$ \\
\hline IL-06 & 26.6 & 4 & 6.83 & 307 & 86.4 & $\mathrm{~nm}$ & 0.2 & 0.011 & $\mathrm{~nm}$ \\
\hline IL-07 & 29.1 & 2 & 6.91 & 303 & 95.6 & $\mathrm{~nm}$ & 0.3 & 0.012 & $\mathrm{~nm}$ \\
\hline IL-08 & 29.7 & 3 & 7.09 & 282 & 91.6 & 6.32 & 0.1 & 0.019 & 0.56 \\
\hline IL-09 & 30.1 & 3 & 7.41 & 283 & 92.3 & 6.46 & 0.2 & 0.015 & 0.09 \\
\hline IL-10 & 25.5 & 9 & 7.13 & 314 & 92.6 & 6.49 & 0.2 & 0.016 & 0.72 \\
\hline IL-11 & 25.4 & 6 & 6.91 & 317 & 72.6 & 6.32 & 0.2 & 0.018 & 0.65 \\
\hline IL-12 & 25.2 & 7 & 6.88 & 308 & 72.9 & 6.37 & 0.2 & 0.015 & 0.90 \\
\hline IL-13 & 25.4 & 1 & 6.78 & 308 & 74.3 & 6.71 & $<0.1$ & 0.015 & 0.94 \\
\hline IL-14 & 26.4 & 2 & 6.63 & 318 & 81.9 & 6.64 & 0.2 & $\mathrm{~nm}$ & 0.67 \\
\hline IL-15 & 26.1 & 1 & 6.87 & 324 & 80.5 & 6.24 & 0.4 & $\mathrm{~nm}$ & 0.84 \\
\hline IL-28 & 25.0 & 4 & 7.28 & 308 & 129.5 & 4.44 & 0.1 & $\mathrm{~nm}$ & 0.72 \\
\hline IL-29 & 25.5 & 3 & 6.53 & 320 & 98.0 & 7.29 & 0.3 & $\mathrm{~nm}$ & 0.58 \\
\hline IL-30 & 25.6 & 3 & 6.94 & 293 & 88.9 & 5.68 & 0.1 & $\mathrm{~nm}$ & 0.76 \\
\hline IL-31 & 26.1 & 2 & 6.84 & 318 & 92.2 & $\mathrm{~nm}$ & 0.5 & $\mathrm{~nm}$ & $\mathrm{~nm}$ \\
\hline IL-32 & 25.0 & 3 & 7.01 & 299 & 84.6 & 5.57 & $<0.1$ & $\mathrm{~nm}$ & 0.09 \\
\hline IL-33 & 25.1 & 2 & 7.04 & 302 & 82.1 & $\mathrm{~nm}$ & 0.3 & $\mathrm{~nm}$ & $\mathrm{~nm}$ \\
\hline IL-34 & 24.8 & 4 & 6.98 & 308 & 82.6 & 5.77 & 0.1 & $\mathrm{~nm}$ & 0.08 \\
\hline IL-35 & 27.0 & 4 & 6.96 & 292 & 80.5 & 9.12 & 0.5 & $\mathrm{~nm}$ & 0.47 \\
\hline IL-36 & 25.4 & 3 & 6.95 & 296 & 84.3 & 4.02 & 0.2 & $\mathrm{~nm}$ & 0.03 \\
\hline IL-37 & 28.9 & 42 & 6.84 & 284 & 104.6 & 4.22 & 0.6 & $\mathrm{~nm}$ & 0.24 \\
\hline IL-38 & 27.6 & 10 & 6.36 & 305 & 156.8 & $\mathrm{~nm}$ & 0.6 & $\mathrm{~nm}$ & $\mathrm{~nm}$ \\
\hline IL-39 & 25.5 & 18 & 6.16 & 296 & 214.0 & 3.90 & 0.8 & $\mathrm{~nm}$ & 0.26 \\
\hline IL-40 & 25.5 & 18 & 6.53 & 296 & 188.1 & 4.46 & 0.6 & $\mathrm{~nm}$ & 0.33 \\
\hline IL-41 & 26.8 & 2 & 6.9 & 305 & 86.5 & 6.01 & 0.1 & $\mathrm{~nm}$ & 0.31 \\
\hline IL-42 & 25.9 & 19 & 6.89 & 272 & 185.9 & $\mathrm{~nm}$ & 0.5 & $\mathrm{~nm}$ & $\mathrm{~nm}$ \\
\hline IL-43 & 25.7 & 2 & 7.16 & 302 & 87.2 & 6.02 & 0.2 & $\mathrm{~nm}$ & 0.01 \\
\hline IL-44 & 25.2 & 3 & 6.66 & 314 & 105.8 & 4.99 & 0.6 & $\mathrm{~nm}$ & 0.74 \\
\hline${ }^{2} \mathrm{RW}$ & $\mathrm{nm}$ & $\mathrm{nm}$ & 6.20 & $\mathrm{~nm}$ & 62.0 & $\mathrm{~nm}$ & $\mathrm{~nm}$ & $\mathrm{~nm}$ & $\mathrm{~nm}$ \\
\hline $\begin{array}{l}\text { Mean } \\
{ }^{3} \text { LAR }\end{array}$ & 26.4 & 6.8 & 6.89 & 299 & 108.0 & 5.90 & 0.30 & 0.039 & 0.75 \\
\hline
\end{tabular}

${ }^{1}$ Sampled in December 4, 2020; ${ }^{2} \mathrm{RW}=$ rainwater; ${ }^{3} \mathrm{LAR}=$ Lambari river; $\mathrm{nm}=$ not measured 
Table 2: Hydrochemical data (in $\mathrm{mg} / \mathrm{L}$ ) of major constituents obtained in the water samples analysed in this study.

\begin{tabular}{|c|c|c|c|c|c|c|c|c|c|c|}
\hline Sample & $\mathrm{Na}^{+}$ & $\mathrm{K}^{+}$ & $\mathrm{Ca}^{2+}$ & $\mathrm{Mg}^{2+}$ & ${ }^{1} \mathrm{Alk}$ & $\mathrm{Cl}^{-}$ & $\mathrm{NO}_{3}^{-}$ & $\mathrm{SO}_{4}^{2-}$ & $\mathrm{SiO}_{2}$ & TDS \\
\hline \multicolumn{11}{|l|}{ code } \\
\hline IL-01 & 7.36 & 3.55 & 3.56 & 0.98 & 40 & 1.9 & 1.3 & 2 & 6.2 & 66.85 \\
\hline IL-02 & 52.21 & 10.32 & 11.4 & 0.92 & 108 & 48.8 & 25.8 & 27 & 15.4 & 299.85 \\
\hline IL-03 & 11.96 & 3.43 & 0.03 & 0.65 & 50 & 3.2 & 1.7 & $<1$ & 7.1 & 78.07 \\
\hline IL-04 & 17.25 & 4.22 & 3.76 & 0.90 & 64 & 9.9 & 2.4 & $<1$ & 7.7 & 110.13 \\
\hline IL-05 & 14.49 & 4.03 & 3.92 & 0.69 & 52 & 7.3 & 2.4 & 1 & 5.2 & 91.02 \\
\hline IL-06 & 9.89 & 1.99 & 0.46 & 0.56 & 34 & 2.7 & 1.5 & 1 & 1.1 & 53.20 \\
\hline IL-07 & 9.43 & 4.26 & 4.04 & 1.01 & 34 & 4.6 & 0.7 & 1 & 0.8 & 59.84 \\
\hline IL-08 & 9.66 & 4.14 & 3.52 & 0.99 & 34 & 4.6 & 0.8 & $<1$ & 1.1 & 58.81 \\
\hline IL-09 & 9.43 & 4.14 & 3.92 & 1.00 & 30 & 4.3 & 0.6 & $<1$ & 2.0 & 55.39 \\
\hline IL-10 & 9.20 & 4.03 & 4.12 & 1.66 & 30 & 4.9 & 1.5 & 1 & 7.6 & 64.00 \\
\hline IL-11 & 7.82 & 3.05 & 1.46 & 1.34 & 24 & 3.8 & 0.8 & $<1$ & 5.5 & 47.77 \\
\hline IL-12 & 7.82 & 3.01 & 4.12 & 1.38 & 24 & 3.9 & 0.9 & 1 & 7.8 & 53.93 \\
\hline IL-13 & 8.05 & 2.85 & 1.52 & 1.30 & 24 & 3.6 & 1.1 & $<1$ & 6.8 & 49.22 \\
\hline IL-14 & 8.28 & 3.36 & 1.50 & 1.34 & 26 & 4.5 & 1.1 & $<1$ & 7.3 & 53.38 \\
\hline IL-15 & 8.74 & 2.38 & 4.84 & 1.38 & 30 & 4.0 & 2.1 & 1 & 9.2 & 63.64 \\
\hline IL-28 & 12.19 & 4.38 & 1.92 & 1.06 & 34 & 8.4 & 1.7 & 1 & 7.0 & 71.65 \\
\hline IL-29 & 12.42 & 2.46 & 2.26 & 0.92 & 28 & 6.1 & 2.1 & 1 & 7.6 & 62.86 \\
\hline IL-30 & 12.42 & 2.38 & 2.34 & 0.90 & 22 & 5.9 & 1.5 & 1 & 5.2 & 53.64 \\
\hline IL-31 & 13.11 & 2.23 & 2.36 & 0.94 & 24 & 6.4 & 1.9 & 1 & 1.7 & 53.63 \\
\hline IL-32 & 12.88 & 1.99 & 2.36 & 0.92 & 24 & 5.8 & 1.4 & 1 & 4.4 & 54.75 \\
\hline IL-33 & 13.34 & 1.92 & 2.38 & 0.90 & 22 & 6.6 & 1.1 & $<1$ & 7.3 & 55.53 \\
\hline IL-34 & 14.49 & 1.92 & 2.40 & 0.90 & 22 & 6.7 & 1.2 & $<1$ & 6.8 & 56.40 \\
\hline IL-35 & 15.18 & 1.88 & 2.46 & 0.86 & 24 & 6.1 & 1.3 & 1 & 6.2 & 58.97 \\
\hline IL-36 & 16.79 & 1.88 & 2.44 & 0.90 & 24 & 7.0 & 1.6 & $<1$ & 6.8 & 61.40 \\
\hline IL-37 & 11.73 & 0.59 & 5.24 & 1.64 & 42 & 6.8 & 0.8 & 1 & 5.9 & 75.69 \\
\hline IL-38 & 27.83 & 1.41 & 2.18 & 0.98 & 32 & 29.2 & 0.5 & 9 & 3.0 & 106.09 \\
\hline IL-39 & 27.60 & 6.99 & 1.80 & 1.08 & 38 & 36.2 & 0.4 & 3 & 5.9 & 120.97 \\
\hline IL-40 & 27.60 & 1.37 & 1.78 & 1.12 & 38 & 11.6 & 0.5 & 1 & 4.7 & 87.66 \\
\hline IL-41 & 11.50 & 2.03 & 1.94 & 0.98 & 22 & 4.2 & 1.1 & 9 & 5.9 & 58.65 \\
\hline IL-42 & 27.83 & 1.37 & 1.86 & 1.14 & 40 & 32.2 & 0.6 & 1 & 3.9 & 109.89 \\
\hline IL-43 & 12.65 & 2.62 & 2.02 & 0.98 & 22 & 4.7 & 0.6 & 9 & 7.8 & 62.37 \\
\hline IL-44 & 11.73 & 2.38 & 2.22 & 0.89 & 36 & 6.0 & 1.7 & $<1$ & 6.3 & 67.22 \\
\hline${ }^{2} \mathrm{RW}$ & 5.98 & 0.74 & 0.95 & 0.30 & 18 & 0.8 & 1.0 & 1 & 1.5 & 30.27 \\
\hline $\begin{array}{l}\text { Mean } \\
{ }^{3} \text { LAR }\end{array}$ & 13.57 & 2.85 & 2.60 & 1.04 & 32 & 8.2 & 1.2 & 1.5 & 5.9 & 68.83 \\
\hline
\end{tabular}

${ }^{1} \mathrm{Alk}=$ alkalinity (bicarbonate); ${ }^{2} \mathrm{RW}=$ rainwater; ${ }^{3} \mathrm{LAR}=$ Lambari river; $\mathrm{nm}=$ not measured 


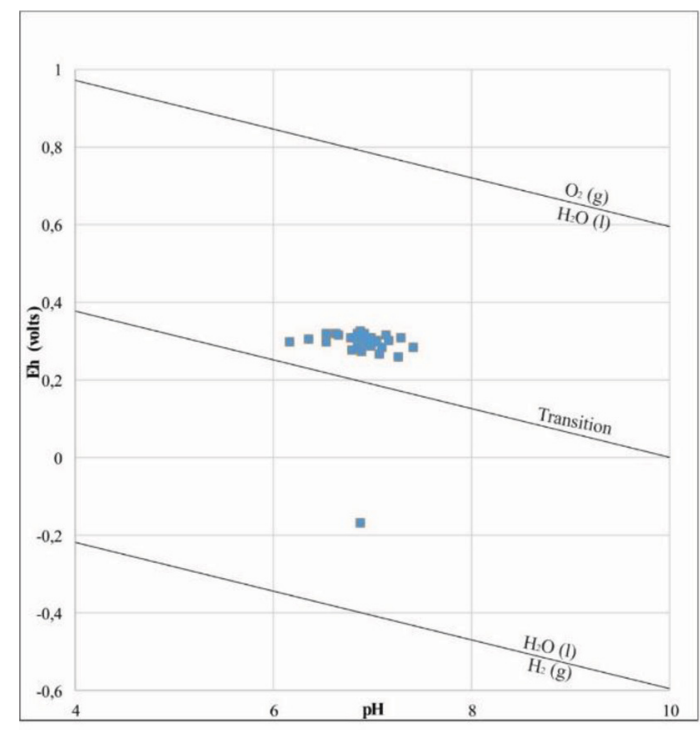

Figure 2: Data obtained for the surface waters of Lambari river analysed in this study inserted in an Eh-pH diagram.
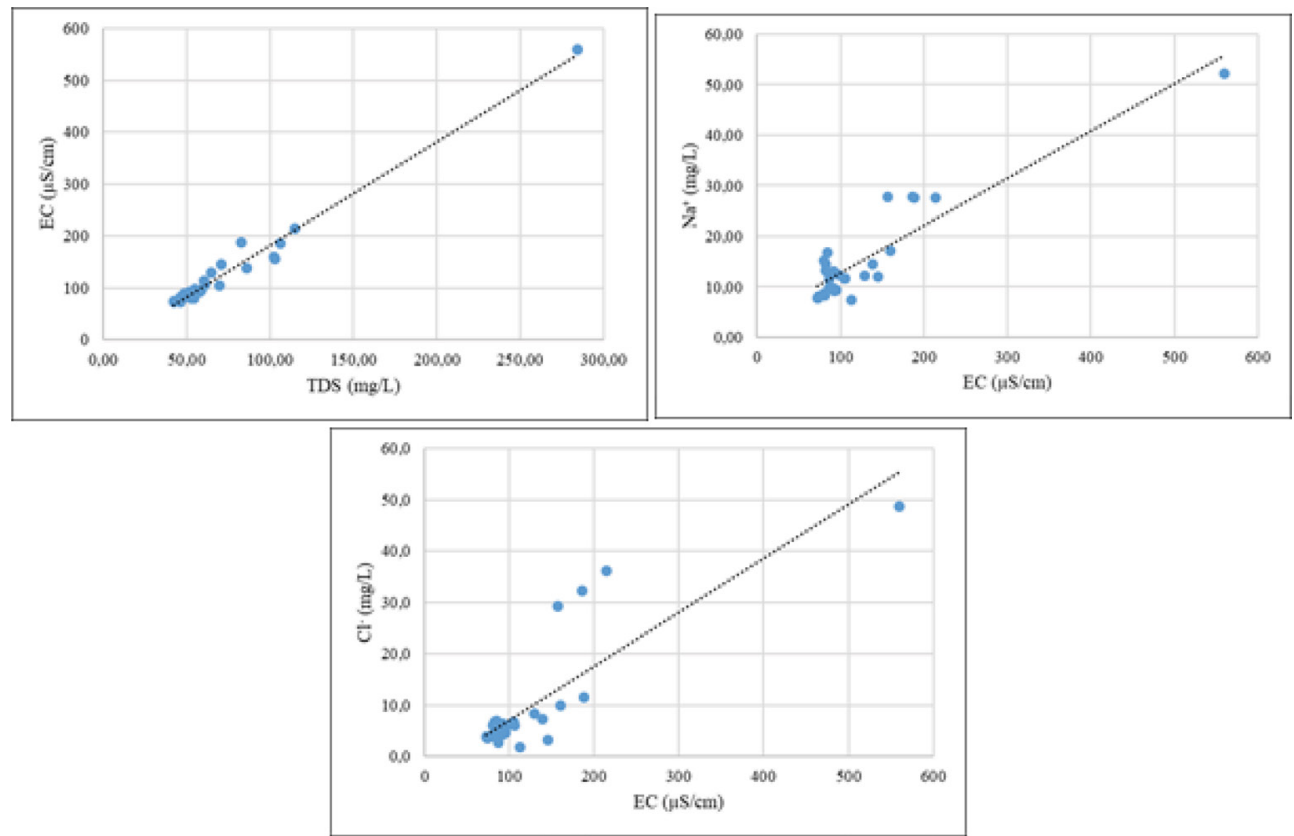

Figure 3: The EC-TDS (upper left), Na-EC (upper right), and Cl-EC (bottom) relationships obtained for all surface water samples of Lambari river analysed in this study. 
The surface waters composition is enhanced in major dissolved constituents relatively to rainwater, as often expected in the hydrological cycle (Figs. 4 and 5). This may be a consequence of the rainfall interactions with the soil covers/rock surfaces or anthropogenic inputs into the river channel.

Comparison of all hydrochemical data obtained for the major constituents reveals direct influence of the rainwater in the surface waters composition as shown in the Piper diagram [22] (Fig. 6). This diagram highlights that the hydrochemical facies of both water types corresponds to sodium bicarbonate, as also confirmed by the diagram of Schoeller [21] (Fig. 5).

Gibbs [23] proposed diagrams for plotting hydrogeochemical data of surface water samples taking into account the processes of rainfall, evaporation and interactions of waterrocks/soils. Figure 7 shows the analytical data reported in Table 2 as plotted in both Gibbs boomerang diagrams, which suggest dominant influence of the dilution effects by rainwater in the hydrochemical composition of the surface waters of Lambari river.

In studies focusing hydrographic basins, Kumar [24] pointed the difficulties of a better understanding of the lithological aspects due to the wide range of factors involved such as the weathering of silicates, dissolution of carbonates and evaporates, etc. Thus, more refined diagrams have been suggested considering, for instance, plots involving ratios of the major ions $\mathrm{HCO}_{3}^{-}, \mathrm{Na}^{+}, \mathrm{Ca}^{2+}$ and $\mathrm{Mg}^{2+}$ [24]. Figure 8 shows the insertion in such plots of the dataset obtained in this study for the surface waters of Lambari river. Despite their preponderant bicarbonate facies (Figs. 5 and 6), the plots of the ratios bicarbonate/sodium vs. calcium/ sodium and magnesium/sodium vs. calcium/sodium don't indicate that the dissolution of carbonates are the dominant processes (Fig. 8). Thus, the silicates weathering takes a major role on controlling the solutes content in the surface waters of Lambari river (Fig. 8).

The radon activity concentration range was $0.01-5.93 \mathrm{~Bq} / \mathrm{L}$ (Table 1 ). The highest value was measured at sample IL-01 that was collected in a farm close to a highway, where the water body is relatively stagnant, thus characterizing little aeration and favouring the radon retention. If the reading in IL-01 is considered an outlier value that could be disregarded, then the Pearson correlation coefficient considering the remaining dissolved oxygen and radon data is $r=0.43$ (Fig. 9), suggesting a linear relationship between these parameters.

The null hypothesis significance testing by calculating the $p$-value from Pearson correlation coefficients has been traditionally adopted for checking the reliability of the results

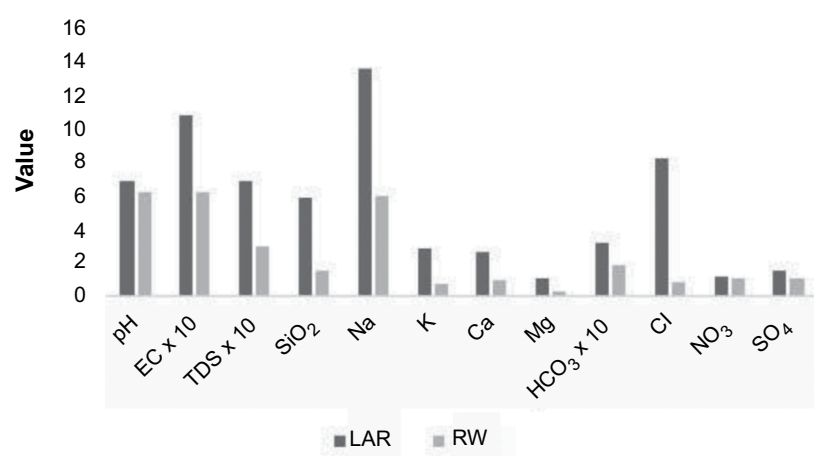

Figure 4: Comparison of physicochemical and major constituents data in rainwater and surface waters sampled at the study area. $\mathrm{LAR}=$ mean value in Lambari river; $\mathrm{RW}=$ rainwater. $\mathrm{pH}$ is unit less, $\mathrm{EC}$ in $\mu \mathrm{S} / \mathrm{cm}$ and other parameters in $\mathrm{mg} / \mathrm{L}$. 


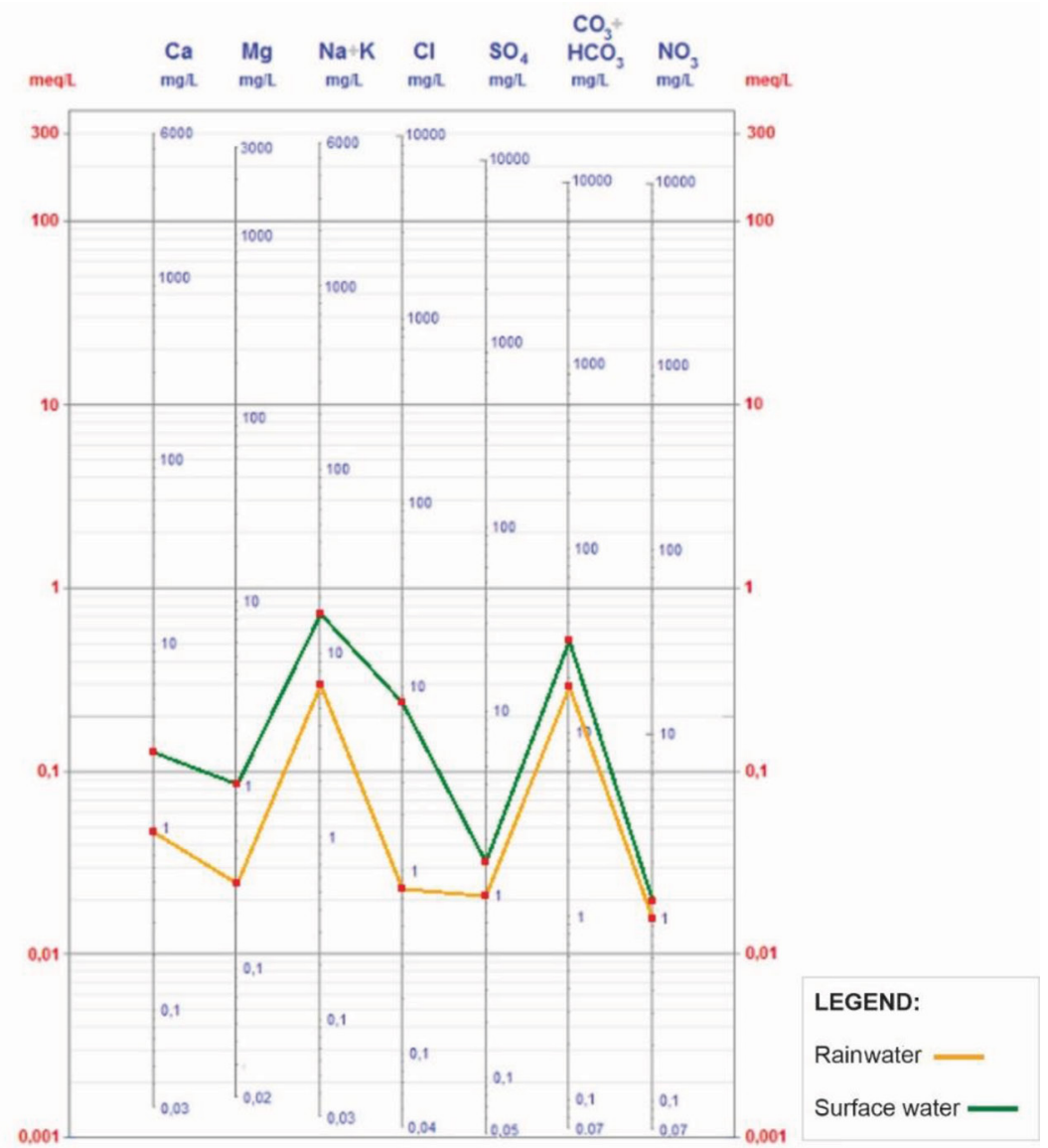

Figure 5: Data for major cations and anions of the waters analysed in this study plotted in a Schoeller diagram [21]. Surface water corresponds to the mean value obtained in the monitoring points at Lambari river.

obtained [25]. The p-value is the probability of obtaining test results at least as extreme as the results actually observed, under the assumption that the null hypothesis is correct. A very small $p$-value means that such an extreme observed outcome would be very unlikely under the null hypothesis. For the dissolved oxygen and radon dataset $(r=0.43 ; n=24)$, the twotailed $p$-value estimate is 0.036 and, by conventional criteria, this difference is considered to be statistically significant. Therefore, both gases oxygen and radon would be congruently dissolved along the investigated sector of Lambari river.

\subsection{Water quality constraints}

The turbidity of the Lambari river waters correlated significantly with TDS (Pearson's correlation coefficient $\mathrm{r}=0.90$ ) as expected once the water body turbidity is directly associated with the levels of dissolved and suspended solids. For 10 samples (31\%), the results exceeded the maximum value allowed by the Brazilian Ministry of Health for drinking water 


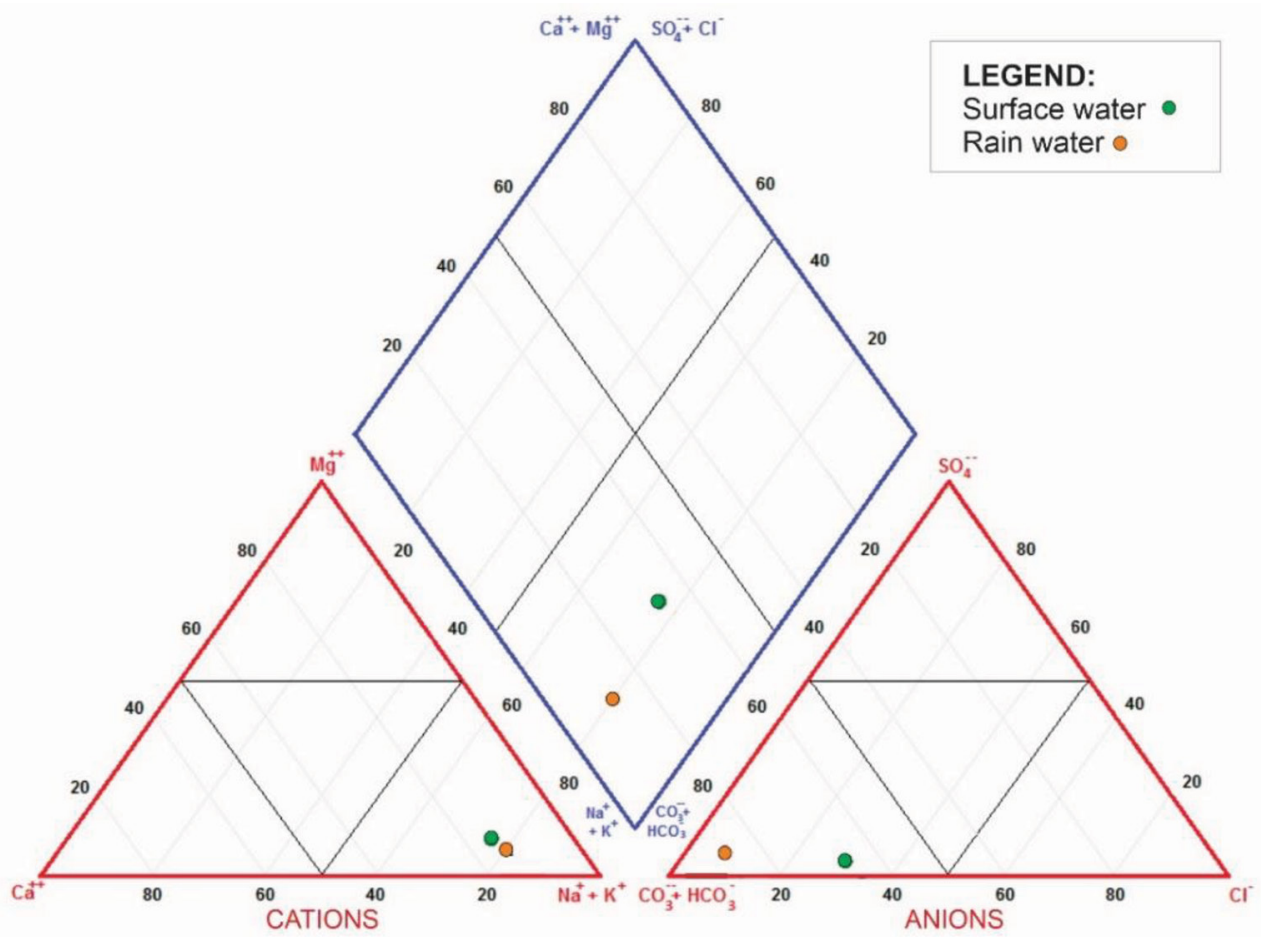

Figure 6: Data for major cations and anions of the waters analysed in this study plotted in a Piper diagram [22]. Surface water corresponds to the mean value obtained in the monitoring points at Lambari river.

corresponding to 5 FTU [26]. For TDS, all values are within the drinking requirements of the Brazilian Ministry of Health corresponding to $1,000 \mathrm{mg} / \mathrm{L}$ [26].

The calcium concentration range in the waters of Lambari river was 0.03-5.24 mg/L, except for the sample IL-02 that corresponded to $11.4 \mathrm{mg} / \mathrm{L}$ (Table 2). For magnesium, the range was $0.56-1.66 \mathrm{mg} / \mathrm{L}$ (Table 2). The Brazilian Ministry of Health [26] allows up to 500 $\mathrm{mg} / \mathrm{L}$ of $\mathrm{Ca}$ and $\mathrm{Mg}$ in drinking water that is a value well above of those found in the analysed surface waters.

The maximum sodium concentration in drinking water allowed by the Brazilian Ministry of Health is $200 \mathrm{mg} / \mathrm{L}$ [26] that is above the values found here for the waters of Lambari river (7.36-52.21 mg/L) (Table 2).

The maximum nitrate concentration in drinking water allowed by the Brazilian Ministry of Health is $10 \mathrm{mg} / \mathrm{L}$ [26] that is above the range 0.4-2.4 $\mathrm{mg} / \mathrm{L}$ found here, except for sample IL-02 of Lambari river that surpassed it $(25.8 \mathrm{mg} / \mathrm{L})$, which may refer to contamination by septic tanks and sewage effluents.

The chloride levels in Lambari river waters were between 1.9 and $48.8 \mathrm{mg} / \mathrm{L}$ (Table 2) that are lower than the guideline reference value of $250 \mathrm{mg} / \mathrm{L}$ in drinking water, according to the Brazilian Ministry of Health [26]. 

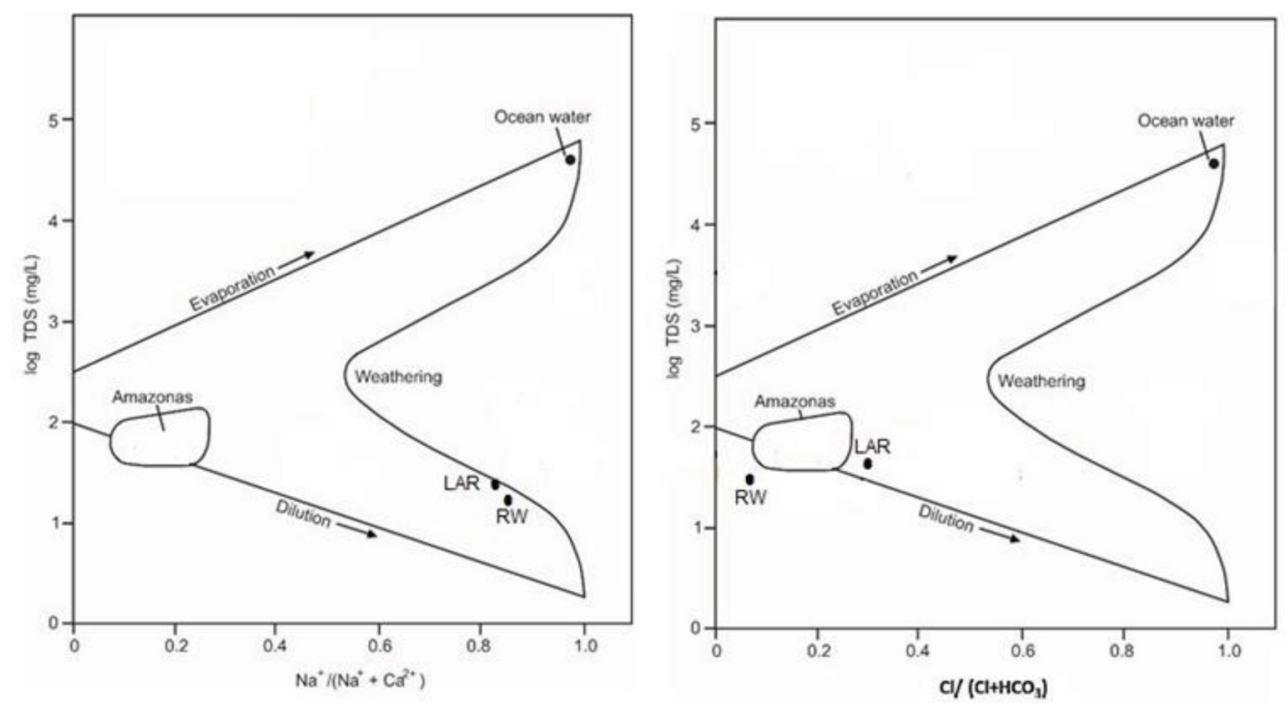

Figure 7: Hydrochemical data obtained in this study for the surface waters composition of Lambari river plotted in a Gibbs diagram [23]. The field Amazonas represents data obtained in Amazonas river. LAR corresponds to the mean value obtained in the monitoring points. $\mathrm{RW}=$ rainwater.
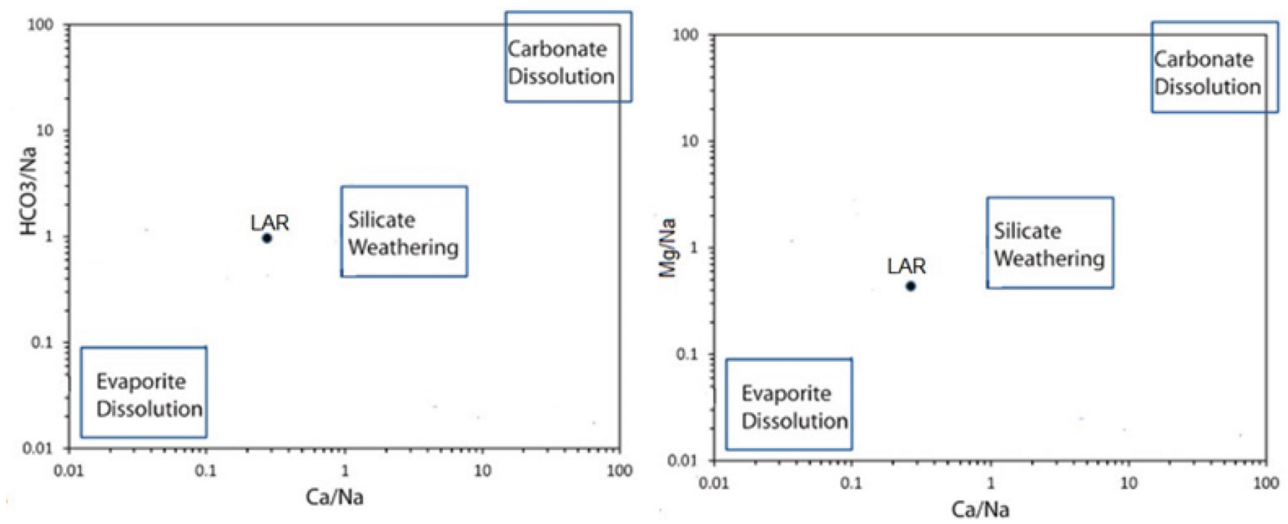

Figure 8: (left) Bivariate plot of $\mathrm{HCO}_{3}{ }^{-} / \mathrm{Na}^{+} \mathrm{vs}$. $\mathrm{Ca}^{2+} / \mathrm{Na}^{+}$and (right) Bivariate plot of $\mathrm{Mg}^{2+} / \mathrm{Na}^{+}$ vs. $\mathrm{Ca}^{2+} / \mathrm{Na}^{+}$for identifying weathering processes in the study area from the surface waters composition of Lambari river. LAR corresponds to the mean value obtained in the monitoring points.

The maximum sulphate concentration in drinking water allowed by the Brazilian Ministry of Health is $250 \mathrm{mg} / \mathrm{L}$ [26] that is above the values found here in Lambari river waters $(<1$ to $27 \mathrm{mg} / \mathrm{L}$ ) (Table 2). 


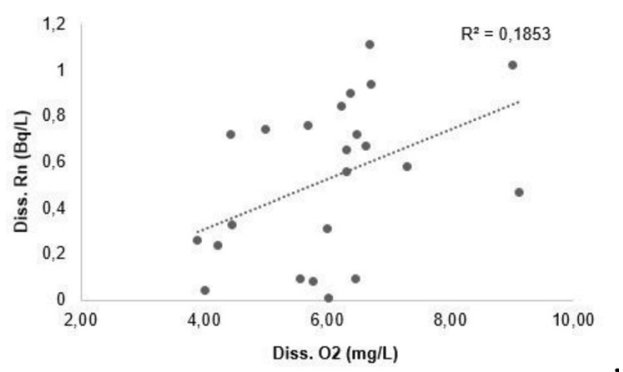

Figure 9: The relationships of dissolved oxygen and radon for all surface water samples of Lambari river analysed in this study.

The analysis of surfactants in Lambari river waters yielded a range of $0.011-0.302 \mathrm{mg} / \mathrm{L}$ (Table 1), indicating an accentuated presence of these compounds in the outlier sample IL-02 that is close to the maximum allowed by the Brazilian Ministry of Health $(0.5 \mathrm{mg} / \mathrm{L})$ [26]. The tannin-lignin level was also higher in the water sample IL-02 $(2.6 \mathrm{mg} / \mathrm{L}$; Table 1$)$, indicating a greater influence of plants decomposition occurring there. In the monitoring point IL-02, the high concentration of surfactants along with the high levels of chloride $(48.8 \mathrm{mg} / \mathrm{L})$ and nitrate $(25.8 \mathrm{mg} / \mathrm{L})$ suggests contamination by domestic effluents, such as cleaning products, cosmetics and sewage effluents. It is likely that the outliers of the physicochemical parameters turbidity (120 FTU), Eh $(-170 \mathrm{mV})$ and EC $(560 \mu \mathrm{S} / \mathrm{cm})$ (Table 1) analysed in the sample IL-02 of Lambari river are related to these contaminants inputs.

The Brazilian standards do not comprise guidelines for Radon $\left({ }^{222} \mathrm{Rn}\right)$ activity concentration in drinking water, but $1 \mathrm{~Bq} / \mathrm{L}$ and $0.1 \mathrm{~Bq} / \mathrm{L}$ have been established for ${ }^{226} \mathrm{Ra}$ (progenitor of ${ }^{222} \mathrm{Rn}$ ) and ${ }^{228} \mathrm{Ra}$, respectively [27]. WHO [7] recommended maximum gross alpha and gross beta values in water-supply systems corresponding to $0.5 \mathrm{~Bq} / \mathrm{L}$ and $1 \mathrm{~Bq} / \mathrm{L}$, respectively. The Brazilian Code of Mineral Waters (BCMW) considered the presence of dissolved radon as a criterion for classifying the mineral waters, based on the Mache unit, MU (1 MU $=10.2$ $\mathrm{Bq} / \mathrm{L}$ ) [28]. According to the BCMW guidelines, values below $5 \mathrm{MU}$ per litre indicate the waters are non-radioactive that is the case of all waters of Lambari river analysed in this paper.

Table 3 reports the results of the analysis of BTEX and other organic compounds in the samples collected at Lambari river upstream (sample 1) and downstream (sample 2) of REVAP area. The concentrations of benzene, toluene, ethyl-benzene, total xylene and total BTEX were lower than $1 \mu \mathrm{g} / \mathrm{L}$ for samples 1 and 2 , indicating they are within the limits established by the Brazilian Ministry of Health [26] that correspond to the maximum permitted values of $5.0 \mu \mathrm{g} / \mathrm{L}$ (benzene), $0.17 \mathrm{mg} / \mathrm{L}$ (toluene), $0.2 \mathrm{mg} / \mathrm{L}$ (ethylbenzene) and $0.3 \mathrm{mg} / \mathrm{L}$ (total xylenes), for the aforementioned compounds, respectively. For p-bromofluorobenzene and toluene d8, the concentrations are, respectively, 18 and $19.5 \mu \mathrm{g} / \mathrm{L}$ (sample 1) and 19.2 and $19.3 \mu \mathrm{g} / \mathrm{L}$ (sample 2). The Brazilian Ministry of Health does not establish a maximum value allowed for drinking water regarding the p-bromofluorobenzene and toluene $\mathrm{d} 8$ concentrations. Therefore, the analytical data did not indicate changes in the concentration of BTEX and other organic compounds in the waters of Lambari river due to the industrial activities developed by REVAP. 
Table 3: Analysis of BTEX and other organic compounds in samples collected at Lambari river. Sampling date December 4, 2020.

\begin{tabular}{llll}
\hline Parameter & & Sample 1 & Sample 2 \\
\hline \multirow{2}{*}{ Benzene $(\mu \mathrm{g} / \mathrm{L})$} & Value $(\mu \mathrm{g} / \mathrm{L})$ & $<1$ & $<1$ \\
& Uncertainty & 0.0671 & 0.0671 \\
Toluene $(\mu \mathrm{g} / \mathrm{L})$ & Value $(\mu \mathrm{g} / \mathrm{L})$ & $<1$ & $<1$ \\
& Uncertainty & 0.0774 & 0.0774 \\
Ethylbenzene $(\mu \mathrm{g} / \mathrm{L})$ & Value $(\mu \mathrm{g} / \mathrm{L})$ & $<1$ & $<1$ \\
& Uncertainty & 0.0592 & 0.0592 \\
o-Xylene $(\mu \mathrm{g} / \mathrm{L})$ & Value $(\mu \mathrm{g} / \mathrm{L})$ & $<1$ & $<1$ \\
& Uncertainty & 0.0539 & 0.0539 \\
m+p Xylene $(\mu \mathrm{g} / \mathrm{L})$ & Value $(\mu \mathrm{g} / \mathrm{L})$ & $<2$ & $<2$ \\
& Uncertainty & 0.1272 & 0.1272 \\
Xylene total $(\mu \mathrm{g} / \mathrm{L})$ & Value $(\mu \mathrm{g} / \mathrm{L})$ & $<1$ & $<1$ \\
& Uncertainty & 0.0636 & 0.0636 \\
BTEX total $(\mu \mathrm{g} / \mathrm{L})$ & Value $(\mu \mathrm{g} / \mathrm{L})$ & $<1$ & $<1$ \\
p-Bromofluorobenzene $(\mu \mathrm{g} / \mathrm{L})$ & Uncertainty & 0.0774 & 0.0774 \\
Toluene d8 $(\mu \mathrm{g} / \mathrm{L})$ & Value $(\mu \mathrm{g} / \mathrm{L})$ & 18 & 19.2 \\
\hline
\end{tabular}

\section{CONCLUSION}

The Paraíba do Sul hydrographic basin is located in a region that is an important economic axis between São Paulo and Rio de Janeiro cities in Brazil. The area possesses a great demand for water resources because comprises large and medium-sized cities, such as Jacareí, Taubaté, Aparecida do Norte and São José dos Campos at São Paulo State. Lambari river is an important tributary of Paraíba do Sul river, crossing the REVAP at São José dos Campos city before its discharge into the major drainage system. Samples of rainwater and surface waters providing from several monitoring points at Lambari river were collected and analysed for physicochemical and hydrochemical parameters with the purpose of evaluating possible release of contaminants into the hydrological resources. One outlier water sample of Lambari river (IL-02) presented distinct values for most of the parameters analysed, i.e. turbidity (120 FTU), redox potential Eh $(-170 \mathrm{mV})$, electrical conductivity (EC) $(560 \mu \mathrm{S} / \mathrm{cm})$, sodium $(52.2 \mathrm{mg} / \mathrm{L})$, potassium $(10.3 \mathrm{mg} / \mathrm{L})$, calcium $(11.4 \mathrm{mg} / \mathrm{L})$, bicarbonate $(108 \mathrm{mg} / \mathrm{L})$, chloride (48.8 mg/L), nitrate $(25.8 \mathrm{mg} / \mathrm{L})$, sulphate $(27 \mathrm{mg} / \mathrm{L})$, silica $(15.4 \mathrm{mg} / \mathrm{L})$, Total Dissolved Solids (TDS) $(299.8 \mathrm{mg} / \mathrm{L})$, surfactants $(0.302 \mathrm{mg} / \mathrm{L})$ and tannin-lignin $(2.6 \mathrm{mg} / \mathrm{L})$. In that monitoring point, the composition could be related to an excessive contribution of domestic effluents as evidenced by its high surfactants level and also by sewage effluents as indicated by its higher concentration of chloride and nitrate. This is corroborated by the fact that the collection point of sample IL-02 is located close to a sewage pipe. Another outlier 
water sample of Lambari river (IL-01) was identified considering the activity concentration of dissolved radon, which corresponded to $5.9 \mathrm{~Bq} / \mathrm{L}$. Such sample was collected in a farm close to a highway, where the water body is relatively stagnant, thus characterizing little aeration and favouring the radon retention. Several significant correlations were obtained from the acquired dataset of the Lambari river waters, for instance, between the following pairs of parameters: dissolved oxygen and radon, EC and TDS, EC and sodium, EC and chloride, EC and bicarbonate, and TDS and bicarbonate. Traditional hydrogeochemical diagrams were helpful for revealing important features of the hydrological system investigated. The Schoeller diagram highlighted the enhanced composition of major dissolved constituents in the surface waters compared with rainwater. The Piper diagram showed similar hydrochemical facies of rainwater and surface waters, i.e. sodium bicarbonate. Two Gibbs boomerang diagrams suggested that the hydrochemical composition of Lambari river waters is dominantly influenced by dilution effects caused by rainwater. Plots of the ratios bicarbonate/sodium, calcium/sodium and magnesium/sodium indicated that the silicates weathering takes a major role on controlling the solutes content in the surface waters of Lambari river. The analysis of BTEX and other organic compounds in waters of Lambari river indicated similar values for samples collected upstream and downstream of REVAP area.

\section{REFERENCES}

[1] Lee I.G. \& Bonotto D.M., Hydrochemical parameters in a portion of Paraíba do Sul river hydrographic basin, São José Dos Campos city, São Paulo State, Brazil. WIT Transactions on Ecology and the Environment, 242, WIT Press, 2020. ISSN 1743-3541.

[2] Brasil. Agência Nacional do Petróleo, Gás Natural e Biocombustíveis. Portaria no 309, de 27 de dezembro de 2001. Estabelece as especificações para a comercialização de gasolinas automotivas no Brasil. Diário Oficial da União. 28 dez 2001.

[3] World Health Organization. Environmental Health Criteria; 214. Human exposure assessment. International Programme on Chemical Safety. Geneva: WHO, 2000.

[4] Clayton, C.G., Nuclear Geophysics. Pergamon: Oxford, p. 479, 1983.

[5] Flügge, S., Zimens, K.E., Die bestimmung von korngrossen und diffusionkonstanten aus dem emaniervermogen (Die theorie der emanier-methode). Zeitschrift fur Physikalische Chemie (Leipzig) B42, 179-220.1939.

[6] WHO (World Health Organization), Guidelines for Drinking Water Quality, 4th ed., WHO Press: Geneva, 2011.

[7] Bonotto D.M., Radioactivity in Waters: From England to Guarani, 1st ed., Ed. UNESP: São Paulo (in Portuguese), 2004.

[8] Amorim D.D. \& Ferreira M.E. Um estudo sobre a qualidade das águas do Rio Paraíba do Sul no Vale do Paraíba do Sul no período de 1978 a 1994. Paper presented at: XIII Brazilian Symposium on Water Resources, 2000, Belo Horizonte, MG.

[9] Appi C.J., Freitas E.L. \& Castro J.C. Faciologia e estratigrafia da Bacia de Taubaté. Technical Report, CENPES/Petrobras, 1986.

[10] Chang H.K., Appi C.J., Riccomini C., Castro J.C., Arai M., Freitas E.L. \& Santos Neto F.V. Geologia da Bacia de Taubaté. Paper presented at: Southeastern Geology Symposium, 1989, Rio de Janeiro, RJ, p. 10.

[11] Riccomini C. O rift continental do sudeste do Brasil. [PhD thesis]. São Paulo (SP): University of São Paulo, 1989.

[12] IPT. INSTITUTO DE PESQUISAS TECNOLÓGICAS DE SÃO PAULO. Mapa geológico - quadrícula de São José dos Campos. São Paulo: IPT, 1978. SF-23-Y-D-II. Escala 1:100.000. 
[13] Ross J. \& Moroz I. Mapa Geomorfológico do Estado de São Paulo. Journal of Geography Department, pp. 41-58, 2011.

[14] Kottek, M.; Grieser, J., Beck, C., Rudolf, B. \& Rubel, F. World map of the KöppenGeiger climate classification updated. Meteorologische Zeitschrift, 15(3), pp. 259-263, 2006.

[15] São José dos Campos Climate. Climate Data Web Site Online. [pt.climate-data.org/ america-do-sul/brasil/sao-paulo/sao-jose-dos-campos-6151]. Accessed on: 21 Jan 2020.

[16] HACH. Water Analysis Handbook. 4th ed. Hach Company, Loveland, Colorado, USA, 2000.

[17] Durridge, RAD7 radon detector-user manual. Durridge Co. Inc.: Bedford, MA, USA, 2009.

[18] Durridge, RAD7 RAD H2O radon in water accessory-owner's manual. Durridge Co. Inc.: Bedford, MA, USA, 2009.

[19] Hem J.D. Study and interpretation of the chemical characteristics of natural water. U.S.G.S. Water Supply Paper, 1473, pp. 1-269, 1959.

[20] Faure, G., 1991. Principles and Applications of Inorganic Geochemistry. MacMillan Publishing Co: New York, 626 p.

[21] Schoeller, H. Groundwaters. Paris: Masson \& Cie (in French), 1962.

[22] Piper, A. A graphic procedure in the geochemical interpretation of water-analyses. Transactions of the American Geophysical Union, 25(6), pp. 914-928, 1944.

[23] Gibbs, R.J. Mechanisms controlling world water chemistry. Science, 170, pp. 10881090, 1970.

[24] Kumar, P.J.S. Evolution of groundwater chemistry in and around Vaniyambadi Industrial Area: Differentiating the natural and anthropogenic sources of contamination. Chemie der Erde, 74, pp. 641-651, 2014.

[25] Wasserstein, R.L., \& Lazar, N.A. The ASA's Statement on p-values: context, process, and purpose. The American Statistician, 70(2), pp. 129-133. 2016.

[26] Ministério da Saúde Brasileiro. Portaria No 2914 de 12 de dezembro 2011; Procedimentos de controle e de vigilância da qualidade da água para consumo humano e seu padrão de potabilidade. p. 33, 2011.

[27] Brasil Consolidated ordinance No. 5 of the Ministry of Health published in 28/09/2017 - Consolidates the standards on health actions and services of the Unified Health System. Ministry of Health, Brasilia (in Portuguese), 2017.

[28] DFPM (Division for Supporting the Mineral Production). The mining code, the mineral waters code and how applying research in a mineral deposit, 8th ed., DFPM, Rio de Janeiro, 1966. 